\title{
PENCEGAHAN TINDAK KEKERASAN TERHADAP PEREMPUAN PERSPEKTIF AL-QUR'AN
}

\author{
Febri Dwijayanti \\ Fakultas Ushuluddin dan Studi Agama, UIN Shulthan Thaha Saifuddin, Jambi, Indonesia \\ febridwijayanti97@gmail.com
}

\begin{abstract}
Abstrak
Penelitian ini dilatarbelakangi oleh realitas yang memprihatinkan, yaitu banyaknya perempuan yang menjadi korban dalam tindak kekerasan rumah tangga. Tindakan tersebut terjadi karena seorang suami merasa bahwa dirinya berhak melakukan apapun terhadap istrinya. Perbedaan yang terjadi antara perempuan dan laki-laki bukanlah tindakan dari diskriminasi. Perbedaan tersebut tidak digunakan untuk meninggikan ataupun merendahkan salah satu makhluk. Salah satu faktor yang memicu tindakan kekerasan tersebut berkaitan dengan bagaimana cara suami dalam menyelesaikan permasalahan. Sedangkan sebagai perempuan kebanyakan mereka menerima segala perlakuan dengan pasrah dan mengalah. Oleh karena itu penulis termotivasi untuk mengkaji tentang tafsiran beberapa ayat yang berkaitan dengan kekerasan terhadap perempuan agar dari penafsiran tersebut dapat ditemukan pencegahannya. Pendekatan penelitian ini menggunakan pendekatan fenomenologi maka, sumber data yang digunakan dalam penulisan skripsi ini adalah fenomena yang terjadi dalam kehidupan rumah tangga dengan menggunakan penelitian kepustakaan (library research). Sedangkan metodologi yang digunakan adalah metode tematik dengan membahas beberapa ayat sesuai dengan tema yang ada di dalam al-Qur'an. Hasilnya penulis menemukan pencegahan dapat dilakukan pada masa awal perkawinan dengan memberikan wejangan dari pihak orang tua serta bagi kedua belah pasangan harus memahami sifat dan kepribadian masingmasing. Kekerasan dalam rumah tangga dapat diatasi pada masa awal sebelum perkawinan. Suami harus memiliki pemikiran yang positif bahwasanya istri adalah titipan Tuhan yang harus yang harus diberikan rasa tanggung jawab, diperlakukan dengan baik seperti dalam awal surah An-Nisa ayat 34 bahwasanya laki-laki adalah pemimpin keluarga. Serta dalam kehidupan rumah tangga harus senantiasa menumbuhkan rasa cinta dan kasih sayang seperti dalam surah Ar-Rum ayat 21.
\end{abstract}

Kata kunci: Pencegahan, Kekerasan, Perempuan

\begin{abstract}
This research is motivated by a worrying reality, namely the number of women who are victims of domestic violence. The action occurs because a husband feels that he has the right to do anything to his wife. The differences that occur between women and men are not acts of discrimination. The difference is not used to raise or lower one of the creatures. One factor that triggers acts of violence is related to how the husband in solving problems. Whereas as women they mostly accept all treatment with resignation and defeatism. Therefore the author is motivated to study the interpretation of some verses relating to violence against women so that the interpretation can be found to prevent it. This research approach uses a phenomenological approach so, the source of the data used in writing this thesis is a
\end{abstract}




\section{AT-TIBYAN}

Journal Of Qur'an and Hadis Studies

Volume. 2 No. 1 (Juni 2019)

phenomenon that occurs in domestic life by using library research. While the methodology used is the thematic method by discussing several verses following the themes in the Qur'an. The results of the authors find prevention can be done in early marriage by advising the parents and for both partners must understand the nature and personality of each. Domestic violence can be overcome in the early period before marriage. The husband must have a positive thought that the wife is entrusted by God that must be given a sense of responsibility, treated well as at the beginning of Sura An-Nisa verse 34 that men are family leaders. And in the life of the household must always foster a sense of love and affection as in surah Ar-Rum verse 21.

Keywords: Prevention, Violence, Women

\section{PENDAHULUAN}

Perempuan merupakan makhluk yang diciptakan untuk mendampingi laki-laki. Perempuan yang diciptakan jelas adalah perempuan yang baik dan sesuai untuk setiap laki-laki, dan sebagai mana laki-laki yang diciptakan adalah yang paling baik untuk perempuannya, karena Sang Pencipta mengetahui apa yang baik untuk ciptaannya.(Shihab, 2018, hlm. 8)

Islam mengajarkan bahwa semua manusia adalah makhluk ciptaan Allah SWT yang sama kedudukannya dihadapan Allah SWT dengan demikian Islam membawa kepada ajaran persamaan manusia, antara laki-laki dan perempuan jelas tidak ada bedanya. Satu- satunya pembeda seseorang menjadi lebih tinggi atau lebih rendah derajatnya adalah nilai pengabdian dan ketaqwaan kepada Allah SWT. Sebagaimana firmannya dalam surah AlHujurat ayat 13 dan An-Nahl ayat 97 berikut:

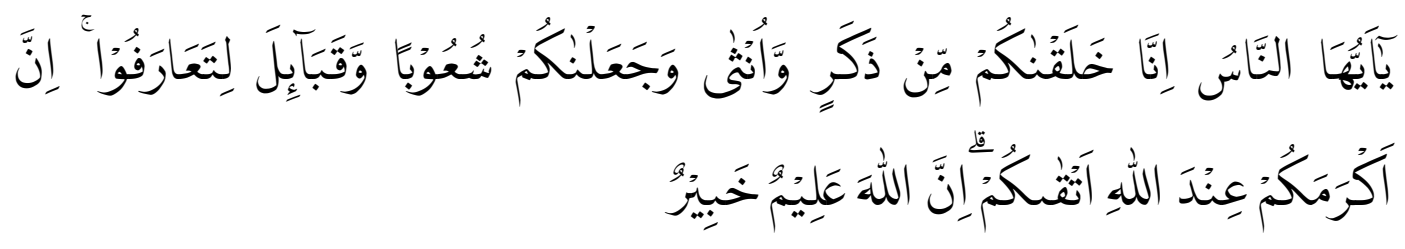

Hai manusia, Sesungguhnya Kami menciptakan kamu dari seorang laki-laki dan seorang perempuan dan menjadikan kamu berbangsa - bangsa dan bersuku-suku supaya kamu saling kenal-mengenal. Sesungguhnya orang yang paling mulia diantara kamu disisi Allah ialah orang yang paling taqwa diantara kamu. Sesungguhnya Allah Maha mengetahui lagi Maha Mengenal."(Lajnah Pentashih al-Qur'an, 2012, hlm. 517)

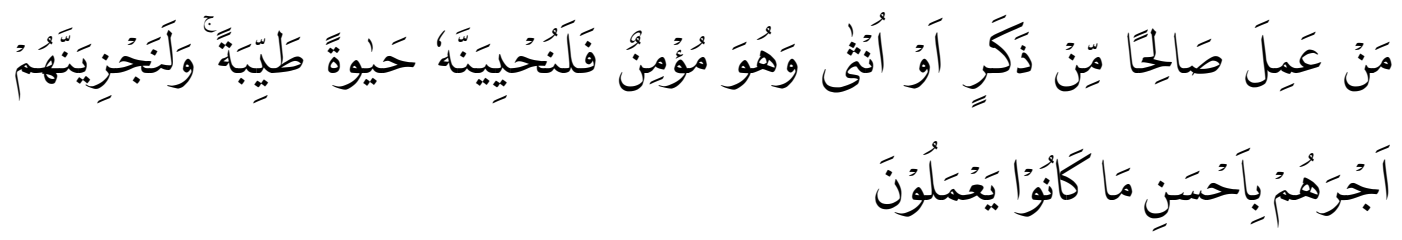


Barangsiapa yang mengerjakan amal saleh, baik laki-laki maupun perempuan dalam Keadaan beriman, Maka Sesungguhnya akan Kami berikan kepadanya kehidupan yang baik dan Sesungguhnya akan Kami beri Balasan kepada mereka dengan pahala yang lebih baik dari apa yang telah mereka kerjakan."(Lajnah Pentashih al-Qur'an, 2012, hlm. 297)

Ayat-ayat tersebut menunjukkan bahwa kedudukan antara laki-laki dan perempuan dalam hal spiritual memiliki tingkat yang sama. Menurut Nasaruddin Umar, Islam mengakui bahwa ada perbedaan antara laki-laki dan perempuan, tetapi bukan pembedaan (discrimination). Perbedaan tersebut dapat dilihat dari fisik dan biologis perempuan yang ditakdirkan berbeda dengan laki-laki, perbedaan tersebut ditunjukkan untuk tidak merendahkan ataupun meninggikan yang lain.(Umar, 1999, hlm. 23)

Namun dalam pemahaman masyarakat, perbedaan tersebut menjadikan alasan terjadinya tindak kekerasan terhadap perempuan yang mana hal tersebut dipicu oleh kebudayaan yang lahir dalam masyarakat tersebut. Misalnya budaya patriaki yang didominasi laki-laki akibatnya banyak kaum perempuan yang mengalami subordinasi, marginalisasi, pelecehan, diskriminasi, eksploitasi dan sebagainya. Kegiatan tersebut sering sekali dikaitkan dengan cara laki-laki dalam menyelesaikan permasalahan. Budaya ini juga memberikan dampak berupa pola pikir perempuan untuk bersikap pasrah, mengalah, mendahulukan kepentingan orang lain, ketergantungan denga laki-laki dan selalu mengutamakan peran sebagai pendamping suami dan pengasuh bagi anak-anak.(Setiawan dkk., 2018, hlm. 134) Oleh karena itu, Islam memandang bahwa kekerasan terhadap perempuan termasuk suatu tindakan yang melanggar hukum.

Hingga saat ini sebagian besar kaum perempuan masih belum menikmati kebebasan sebagaimana yang kini telah dinikmati olek kaum lakilaki. Bahkan masih ada juga perempuan yang menanggung beban karena tindakan semena-mena dari kaum laki-laki. Di antara faktor penyebab masalah ini adalah pandangan kaum laki-laki yang selalu menempatan wanita pada posisi terendah serta tidak memperlakukan kaum perempuan sesuai hak-haknya. Kondisi yang seperti ini mengakibatkan terjadinya perlakuan yang tidak semestinya terhadap perempuan.

Melihat permasalah tersebut penulis tertarik untuk melanjutkan penelitian ini untuk melihat bagaimana bentuk-bentuk kekerasan terhadap perempuan di dalam kehidupan berumah tangga, penyebab yang mempengaruhi terjadinya tindak kekerasan terhadap perempuan di dalam berumah tangga serta bagaimana penafsiran para mufassir mengenai ayatayat kekerasan terhadap perempuan dalam kehidupan berumah tangga. 


\section{PEMBAHASAN}

\section{Bentuk-bentuk kekerasan terhadap perempuan}

Segala bentuk perlakuan yang dilakukan oleh pihak pelaku yang menimbukan perasaan-perasaan yang tidak nyaman dan rasa takut sudah termasuk dalam tindak kekerasan terhadap perempuan. Perlakuan tersebut dapat berbentuk kekerasan fisik maupun non fisik. Perilaku tersebut dapat berupa sentuhan maupun sebuah paksaan. Disamping itu, ada juga kekerasan verbal yang mana biasa berupa ejekan atau tindakan meremehkan perempuan.

Kekerasan terhadap perempuan adalah setiap kekerasan yang diarahkan kepada perempuan hanya karena mereka perempuan. Hal tersebut dipaparkan oleh Harkristuti Harkrisnowo dengan melihat apa yang terjadi terhadap perempuan karena jenis kelaminnya.(Muhajarah, 2017, hlm. 132) Oleh karena itu menurutnya kekerasan dibagi ke dalam beberapa bentuk yaitu;

1. Kekerasan fisik (physical abuse), adalah suatu perbuatan yang berupa siksaan, tamparan, menendang, memukul, menjambak, meludah, penganiayaan, penjambakan, mendorong serta memukul dengan menggunakan senjata seperti; melemparkan batu, pisau, gunting serta pembakaran. Secara umumnya tindak kekerasan fisik adalah berupa penganiayaan, pembunuhan dan pemerkosaan. Bentuk kekerasan tersebut dapat saja terjadi pada suami terhadap istri, istri terhadap suami ataupun suami terhadap anak-anak dan ataupun sebaliknya.

2. Kekerasan psikis/emosional, dapat berupa rasa cemburu, merusak barang milik pribadi, ancaman bunuh diri ataupun ancaman pembunuhan, mencaci maki, tidak diperbolehkan bergaul ataupun bersosialisasi dengan masyarakat dilingkungan rumah maupun keluarga, memberikan persasaan takut melalui intimidasi, dan sebagainya. Kekerasan psikis tersebut dapat mengakibatkan ketakutan, hilangnya rasa percaya diri, rasa tidak berdaya hingga terjadinya penderitaan psikis berat terhadap korban.

3. Kekerasan ekonomi (economic abuse) seperti; membiarkan istri bekerja sementara sang suami tidak memenuhi kebutuhan hidup sehari-hari, melakukan kontrol terhadap penghasilan serta pengeluaran pembelanjaan.

4. Kekerasan seksual (sexual abuse), kejahatan seksual dalam hal ini bias saja digolongkan kepada kekerasan fisisk ataupun psikologis dengan memaksa melakukan pelacuran, memaksa berhubungan seksual 
hingga maraknya kasus prostitusi online dengan perempuan dijadikan seperti barang dagangan.(Muhajarah, 2017, hlm. 132)

\section{Faktor-faktor penyebab terjadinya kekerasan terhadap perempuan}

Adapun faktor yang mempengaruhi terjadinya tindak kekerasan terhadap perempuan dalam rumah tangga khususnya suami terhadap istri adalah sebgai berikut:

\section{Kajian Sosial Budaya}

Tindak kekerasan terhadap perempuan dalam keluarga tidak terjadi secara spontan, namun memiliki sebab-sebab tertentu yang melatarbelakangi laki-laki berbuat demikian. Secara umum penyebab terjadinya kekerasan adalah gender dan patriaki, relasi kekuasaan yang timpang dan role modding.

Gender dan patriaki mengakibatkan kekuasaan yang tidak seimbang karena laki-laki dianggap lebih berkuasa disbanding perempuan yang berakibat pada kedudukan suami yang dianggap memiliki kekuasaan untuk mengatur istri dan anaknya. Anggapan tersebut mengakibatkan laki-laki berpeluang besar untuk melakukan tindak kekerasan.(Muhajarah, 2017, hlm. 133)

Secara sosial budaya ada beberapa faktor yang menjadi penyebab timbulnya kekerasan dalam rumah tangga, antara lain:

a. Budaya patriaki yang mendukung laki-laki sebagai makhluk yang paling berkuasa dan perempuan sebagai makhluk lemah.

b. Pemahaman yang keliru terhadap ajaran agama sehingga menempatkan laki-laki boleh menguasai perempuan.

c. Peniruan anak laki-laki yang hidup bersama ayahnya yang sering melakukan tindak kekerasan terhadap ibunya baik itu kekerasan fisik, psikis maupun seksual.

d. Kondisi kehidupan suami atau keluarga yang hidup dalam kemiskinan.

e. Suami pemabuk, frustasi atau mempunyai kelainan jiwa.(Purba, t.t., hlm. 1-4)

\section{Kajian Hukum dan Perundang-undangan}

Benyaknya peraturan yang berkaitan dengan hukum terhadap perempuan sebagai korban kekerasan saat ini belum responsif. Komponen hukum yang meliputi komponen substansial, struktural dan budaya hukum masyarakat tidak memihak kepada kepentingan perempuan. Seperti; konsep "kekerasan yang berbasis gender" tidak lagi memadai untuk menampung 
realitas kekerasan yang terjadi di masyarakat. Dalam perkataan lain hukum tidak mengakui adanya kekerasan terhadap perempuan.(Muhajarah, 2017, hlm. 134-135)

Kekerasan terhadap perempuan juga terjadi dikarenakan nilai budaya dan tafsir agama yang selanjutnya dibakukan dalam hukum Negara. Hal tersebut menjadikan pendiskreditkan perempuan menjadi sub-ordinate dihadapan laki-laki. Misalnya mengenai surah an-Nisa ayat 34 yang dijadikan legitimasi kekerasan terhadap perempuan (istri) yang tidak patuh.(Muhajarah, 2017, hlm. 136)

Pemahaman, penafsiran dan pemikiran agama yang tidak mustahil dipengaruhi oleh tradisi dan kultur patriaki, ideology kapitalisme maupun pandangan-pandangan lainnya juga dapat menjadi salah satu faktor penyebab terjadinya tindak kekerasan terhadap perempuan. Banyak sejarawan yang mengungkapkan bahwa pada masa pra-islam atau yang lebih dikenal dengan zaman jahiliyah, kedudukan wanita sangatlah memprihatinkan serta dianggap tidak berharga.

\section{Ayat-ayat yang berkaitan dengan pencegahan tindak kekerasan terhadap perempuan}

1. surah an-Nisa' ayat 19 dalam kitab Tafsir al-Azhar karangan Hamka yaitu:
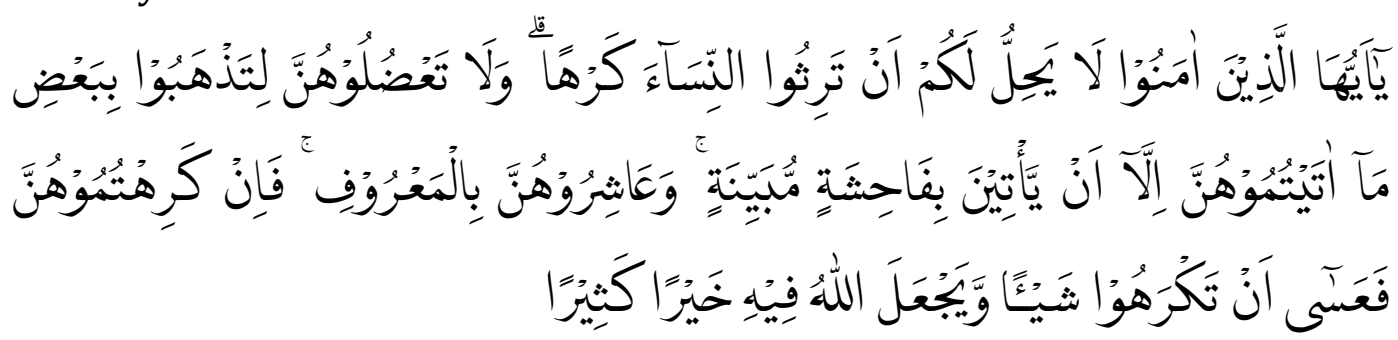

Hai orang-orang yang beriman, tidak halal bagi kamu mempusakai wanita dengan jalan paksa dan janganlah kamu menyusahkan mereka karena hendak mengambil kembali sebagian dari apa yang telah kamu berikan kepadanya, terkecuali bila mereka melakukan pekerjaan keji yang nyata. Dan bergaullah dengan mereka secara patut. Kemudian bila kamu tidak menyukai mereka, (maka bersabarlah) karena mungkin kamu tidak menyukai sesuatu, Padahal Allah menjadikan padanya kebaikan yang banyak.

Dalam pangkal ayat dari surah an-Nisa' ayat 19 ini menerangkan mengenai adat buruk jahiliyah terhadap perempuan. Kebiasaan buruk jahiliyah yang sangat dicela Islam, dan diberi peringatan kepada orang Islam supaya jangan melakukannya lagi. Pertama, memandang perempuan sebagai harta pusaka, sebagai barang warisan dari orang yang telah mati. Kedua, melakukan Adal yaitu membuat hati perempuan itu tersakiti, membuat 
fikirannya menjadi sempit, sehingga akhirnya dia tidak berdaya lagi, menyerah saja kepada si pemeras.(Hamka, 2003, vol. II, hlm. 1135-1136)

Kemudian datanglah lanjutan ayat tersebut sebagai pengecualian, yaitu: "kecuali jika mereka melakukan kekejian yang nyata". Menurut Ibnu Abbas, Qatadah dan adh-Dhahhak yang dimaksud dengan kekejian adalah jika perempuan itu durhaka terhadap suaminya (nushuz) atau memang perangai dan kelakuannya buruk, kasar, tidak sopan. Menurut al-Hasan, kekejian yang nyata adalah jika dia berzina. Tetapi yang perlu diingat dalam ayat ini adalah kekejian yang nyata bukan seperti fitnah, atau tuduhan karena benci, atau mencari-cari hal untuk membuatnya 'adal tidaklah dapat diterima.(Hamka, 2003, vol. II, hlm. 1136)

Dengan keterangan ini jelas sekali, bahwa hak-hak perempuan dilindungi dan mereka tidak boleh diperlakukan sewenang-wenang. Mereka hanya boleh dihukum ketika memang benar-benar melakukan kesalahan. Jika terus saja terjadi pertengkatan, sehingga masing-masing tidak mau mengalah, masing-masing menuduh campur tangan, sebagaimana kelak akan disebutkan dalam ayat 34 .

Kemudian datanglah ayat lanjutannya "pergaulilah mereka dengan cara yang patut" dalam ayat tersebut disebut dengan kata Ma'ruf yang diartikan dengan sepatutnya. Menurut Ibnu Abas pergaulan yang ma'ruf adalah bahwa engkau pakai dihadapan istrimu pakaian yang bersih, bersisisr rambut yang teratur. Berkenaan dengan penafsiran Ibnu Abbas tadi, teringatlah bawa Nabi dapat menyenangkan istrinya. Beliau memiliki kotak kecil untuk menyimpan sisir, siwak dan minyak wangi. Rambut beliau selalu harum. Beliau benci dengan yang kotor, yang kainnya jarang dicuci.(Hamka, 2003, vol. II, hlm. 1137)

Penafsiran dari kitab tafsir al-Azhar sama persis dengan Tafsir alQur'anul Majid An-Nur menjelaskan kalimat pertama "hai orang-orang yang beriman tidak halal bagi kamu menjadikan perempuan harta warisan, sedangkan mereka tidak menyukai hal itu" menjelaskan bahwa perempuan tidak layak diperlakukan seperti harta benda misalnya menjadikannya seperti harta warisan yang bias dipindah tangangankan sesukamu. Tidak halal melakukan perbuatan jahiliyah dengan merampas hak-hak perempuan. Perbuatan orang beriman tidak layak memperlakukan perempuan dengan sesuka hati, misalnya menikahi sewaktu suka, menceraikan sewaktu tidak suka, menikahkan dengan orang lain melalui jalan paksa atau menghalangi dia menikah dengan pilihannya.(al-Shiddieqy, 2000, hlm. 810-811)

Lalu dibagian yang lain "pergaulilah mereka dengan baik dan wajar" maksudnya seorang laki-laki wajib mepergauli istrinya dengan baik sesuai 
ketentuan syara' dan kewajaran umum. Jangan mempersulit nafkahnya dengan terkadang memberi terkadang tidak. Jangan menyakiti perasaannya, baik dengan ucapan atau perbuatan. Kata mu'asyarah memberikan makna persamaan, yaitu suami-istri hendaknya bergaul secara ma'ruf. Keduanya saling menyenangkan yang lain dalam kehidupan dan pergaulan rumah tangga dengan menyampaikan perbedaan-perbedaan atau kesalahan kecil dan juga keduanya harus menumbuhkan rasa saling menyayangi.(alShiddieqy, 2000, hlm. 812)

Dari kedua penafsiran diatas tidak jauh berbeda dengan penjelasan dalam kitab tafsir jalalalin yang mana menerangkan bahwa di zaman jahiliyah mereka biasa mewarisi wanita-wanita, istri karib kerabat mereka. Jika mereka menghendaki , mereka dapat mengawininya tanpa mas kawin, atau mereka kawinkan lalu diambil mas kawinnya, atau menghalangi kawin sampai dia menebus dirinya sendiri dengan harta warisan yang diperoleh atau mereka tunggu sampai meninggal lalu mereka warisi hartanya. Maka

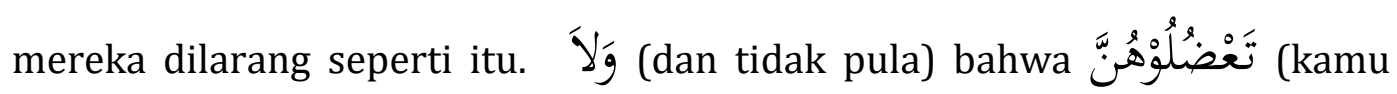
menyusahkan mereka) artinya kamu haling-halangi istri kamu untuk mengawini laki-laki lain dengan menahan mereka padahal tak ada lagi keinginanmu terhadapnya. Selanjutnya jika mereka melakukan perbuatan yang keji atau nyata seperti zina atau nushuz maka ketika itu dibolehkan kamu menyusahkan mereka hingga mereka melakukan khulu' atau menebus

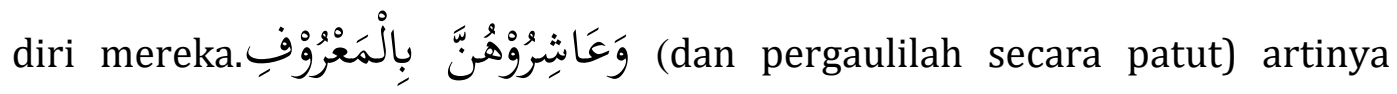
secara baik-baik, baik dalam perkataan, maupun dalam memberi nafkah lahir dan batin.(As-Suyuthi, 2004, vol. I, hlm. 335-336)

\section{2. surah an-Nisa' ayat 34}

ق
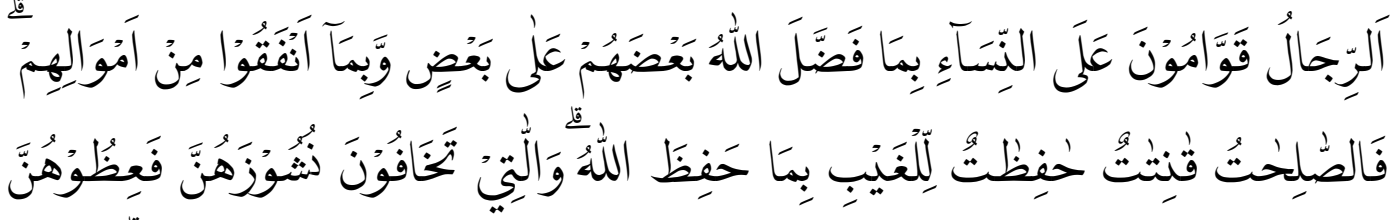

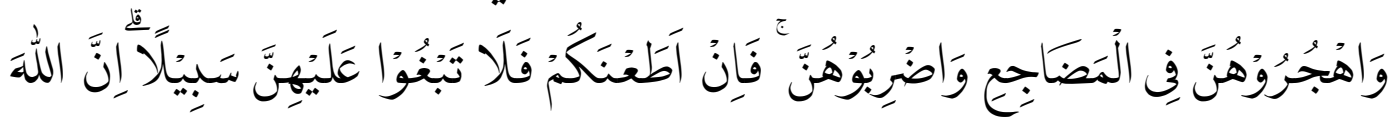
كَانَ عَلِيَّا كَبْرِ

Kaum laki-laki itu adalah pemimpin bagi kaum wanita, oleh karena Allah telah melebihkan sebahagian mereka (laki-laki) atas sebahagian yang lain (wanita), dan karena mereka (laki-laki) telah menafkahkan sebagian dari harta mereka. sebab itu Maka wanita yang saleh, ialah yang taat kepada Allah 


\section{AT-TIBYAN}

Journal Of Qur'an and Hadis Studies

Volume. 2 No. 1 (Juni 2019)

lagi memelihara diri ketika suaminya tidak ada, oleh karena Allah telah memelihara (mereka). wanita-wanita yang kamu khawatirkan nusyuznya, Maka nasehatilah mereka dan pisahkanlah mereka di tempat tidur mereka, dan pukullah mereka. kemudian jika mereka mentaatimu, Maka janganlah kamu mencari-cari jalan untuk menyusahkannya. Sesungguhnya Allah Maha Tinggi lagi Maha besar.

Dalam Tafsir al-Azhar ayat ini penulis langsung mengambil pokok permasalahan mengenai nusyuz yaitu:"dan perempuan yang kamu takut kedurhakaan mereka" yang terkenal dengan bahasa asli nushuz, tidak patuh dan tidak taat kepada Allah maupun kepada suami sebagai pemimpin mereka, maka terhadap istri yang seperti ini tempuhlah tiga cara "maka ajari mereka". Berilah mereka petunjuk dan pengajaran, ajarilah mereka dengan baik, sadarkan mereka akan kesalahannya. "dan memisahlah dari mereka pada tempat-tempat tidur". Memisahkan tempat tidur karena menunjukkan hati tidak senang adalah termasuk pukulan yang agak keras bagi seorang istri. Menurut Ibnu Abbas secara terang-terangan menafsirkan bahwa berpisah seketiduran maksudnya adalah jangan dia disetubuhi, jangan tidur didekatnya, atau belakangi dia ketika sedang tidur.(Hamka, 2003, vol. II, hlm. 1197-1198)

Tetapi ada juga cara menghadapi perempuan dengan lebih kasar. Maka dari itu dipakailah jalan yang ketiga yaitu "dan pukullah mereka". Cara yang ketiga ini dilakukan apabila perempuan tersebut benar-benar pantas dipukul.(Hamka, 2003, vol. II, hlm. 1199)

Menurut Ibnu Abbas menafsirkan "Pukullah, tetapi jangan yang menyebabkan dia menderita." 'Atha' berkata:"Pukullah dengan siwak!". Dalam penjelasan Ulama Fiqh menjelaskan:”Jangan sampai melukai, jangan sampai patah tulang, jangan berkesan dan jauhi memukul muka, karena muka adalah kumpulan segala kecantikan. Hendaklah memukul di bagian yang berbeda-beda bukan disatu tempat, supaya jangan terlalu menyakitkan". Bahkan ada pula yang menyatakan "pukul saja dengan menggunakan tangan yang terbungkus sapu tangan jangan dengan cambunk ataupun tongkat"(Hamka, 2003, vol. II, hlm. 1201)

Dilanjutkan dengan turunnya ayat "Tetapi jika mereka taat kepada kamu, maka janganlah kamu cari-cari jalan buat menyusahkan mereka" yang dimaksud dengan perempuan taat di sini adalah perempuan yang tau mana hak dan kewajibannya, yang menjaga rumah tangganya dan tahu akan tegang menegang dan juga tahu akan harga dirinya. Berlakulah hormat kepada perempuan dalam rumah tangga. Karena kalu istri sudah berbuat demikian baiknya, lalu laki-laki mencari-cari kesalahn jangan disesalkan kalau dia 
melawan. Janganlah suatu kesalahan yang terjadi ditimpakan kepada perempuan, karena perempuan juga manusia. (Hamka, 2003, vol. II, hlm. 1201)

Diterangkan bahwa Allah memperingatkan "Sesungguhnya Allah, adalah Maha Tinggi dan Maha Besar" dalam penafsirannya Allah menghebatkan kepada laki-laki bahwa dia adalah pemimpin bagi perempuan. Oleh karena itu jangan kamu sombong, takabbur, dan jangan membesarkan diri terhadap istrimu. Jangan berbuat sewenang-wenang dalam memegang kekuasaan. (Hamka, 2003, vol. II, hlm. 1201-1202)

Selanjutnya "jika mereka kembali menantimu, janganlah kamu berlaku curang terhadap mereka" maksudnya jika istri merasa bersalah dan menyadari kesalahannya maka janganlah kamu menganiaya dia dan jangan mencari-cari keburukan sifatnya atau mengungkit sikapnya. Tapi jika langkah-langkah tersebut gagal dilakukan maka serahkan pada pihak ketiga (hakam,moderator) dari keluarga laki-laki dan keluarga istri.(al-Shiddieqy, 2000, hlm. 844-845)

Sama halnya dengan penafsiran dari kitab tafsir jalalain menjelasan mengenai perilaku nushuz artinya pembangkangan mereka terhadap kamu, misalnya dengan adanya ciri-cirinya dan ingatkan supaya mereka takut kepada Allah. Yaitu dengan menasehatinya, memisahkan tempat tidur ke ranjang lain dan pukullah mereka dengan pukulan yang tidak melukai, jika mereka masih belum sadar. Jangan mencari-cari jalan untuk memukul mereka secara aniaya.(As-Suyuthi, 2004, vol. I, hlm. 345)

\section{Surah an-Nisa' ayar129}

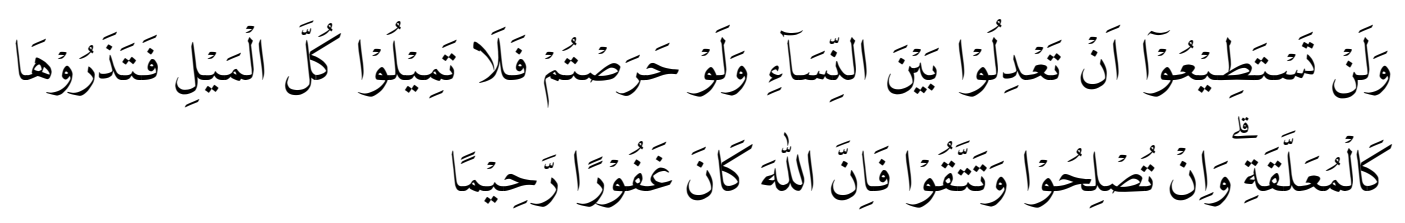

Dan kamu sekali-kali tidak akan dapat Berlaku adil di antara isteri-isteri(mu), walaupun kamu sangat ingin berbuat demikian, karena itu janganlah kamu terlalu cenderung (kepada yang kamu cintai), sehingga kamu biarkan yang lain terkatung-katung. dan jika kamu Mengadakan perbaikan dan memelihara diri (dari kecurangan), Maka Sesungguhnya Allah Maha Pengampun lagi Maha Penyayang.

Di pangkal ayat dalam tafsir al-Azhar dijelaskan mengenai perlakuan adil, yang tidak sanggup mengadilkannya adalah hati. Berbelanja kebutuhan rumah tangga bias diadilkan bagi yang kaya. Pergiliran hari dan malam pun bisa diadilkan. Tapi cinta tidak bisa diadilkan dan Tuhan yang telah 
mentakdirkan demikian pun tidak memaksa hati manusia pada perkara pembagian waktu dan hari, sudah sangatlah adil. Dalam hal tidak mengadilkan hati, Rasulallah SAW bermohon kepada Tuhan dalam doanya:

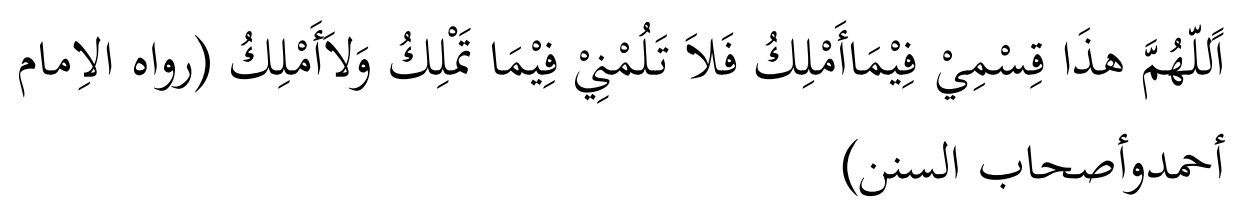

ya Tuhanku, inilah pembagian yang dapat aku berikan pada perkara yang dapat aku kuasai. Maka janganlah engkau sesali aku dalam perkara yang hanya engkau menguasai, dan aku tidaklah berkuasa" (dirawikan oleh Ahmad dan Ash-Habus Sunan)

Lalu datanglah ayat lanjutannya:"sebab itu janganlah condong terlalu condong, sehingga kamu biarkan dia laksana barang tergantung"artinya lakilaki bijaksana akan dapat mengendalikan diri dengan tidak mencondongkan hanya kepada satu istri. Karena dia adalah ibu dari anak-anakmu. Perlakuan ayah yang tidak adil akan menimbulkan kesan yang tidak baik bagi anakanak. Sebab itu janganlah sekali-kali menjadikan istri kurang dicintai laksana barang tergantung. Tergantung tidak bertali, terkatung-katung. Jangan sampai ada aniaya terhadap jiwanya.(Hamka, 2003, vol. II, hlm. 1456-1457)

Sedangkan dalam Tafsir Al-Qur'anul Majid an-Nur diawal ayat dijelaskan janganlah membuat istri terkatung-katung (terlantar), tidak ditalak dan tidak dipergauli dengan baik. Sebagai suami harus meninggalkan rasa berat sebelah sehingga menyebabkan kekecewaan terhadap istri yang lain.(al-Shiddieqy, 2000, hlm. 966-967) Dalam tafsir jalalin juga demikian penjelasannya sama dengan penafsiran tafsir Al-Qur'anul Majid An-Nur. Namun, lebih ditambahkan mengenai pembagian nafkah yang sama rata pula.(As-Suyuthi, 2004, vol. I, hlm. 393)

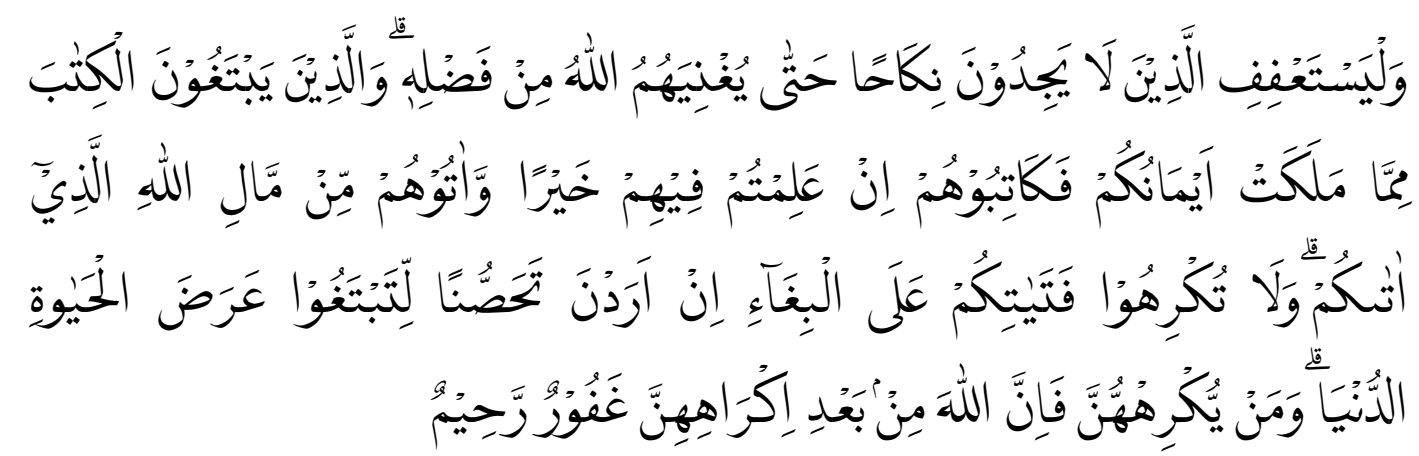

Dan orang-orang yang tidak mampu menikah hendaklah menjaga kesucian (diri)nya, sampai Allah memberi kemampuan kepada mereka dengan karunia-Nya. Dan jika hamba sahaya yang kamu miliki menginginkan 
perjanjian (kebebasan), hendaklah kamu buat perjanjian kepada mereka, jika kamu mengetahui ada kebaikan pada mereka, dan berikanlah kepada mereka sebagian dari harta Allah yang dikaruniakan-Nya kepadamu. Dan janganlah kamu paksa hamba sahaya perempuanmu untuk melakukan pelacuran, sedang mereka sendiri menginginkan kesucian, karena kamu hendak mencari keuntungan kehidupan duniawi. Barangsiapa memaksa mereka, maka sungguh, Allah Maha Pengampun, Maha Penyayang (kepada mereka) setelah mereka dipaksa.

Tafsir al-Azhar "dan janganlah kamu paksa budak-budak wanitamu untuk melakukan pelacuran,sedangkan mereka mengingini kesucian, karena kamu hendak mencari keuntungan duniawi". Pada zaman jahiliyah berlaku adat buruk yaitu seorang budak perempuan dipaksa untuk melakukan perzinaan oleh tuannya, menjadi perempuan lacur, memungut bayaran dari orang yang memakainya, dan bayaran tersebut di setorkan ke tuannya. Sehingga masyarakat jahiliyah melakukan ini dengan tidak malu. Kebetulan kepala orangorang munafik, yaitu Abdullah bin Ubay bin Saul mempunyai mata pencarian kotor ini. Budak perempuannya bernama Ma'azsah yang pada hakikatnya ingin hidup suci dan jijik dengan perbuatannya sendiri yang dilakukannya karena terpaksa dan mengadukan nasibnya kepada Sayyidina Abu Bakar dan memohon beliau sudi menolong melepaskannya daripada hidup yang hina.

Maka dalam ayat-ayat tersebut diatas ini nyatalah masyarakat macam mana yang dikehendaki Islam dan betapa pula pandangan Islam terhadap soal perkawinan dan perkelaminan.(Hamka, 2003, vol. II, hlm. 2937)

Dalam Tafsir Jalalain pun juga menjelaskan bahwa ayat tersebut tidak untuk menjual sahaya perempuan guna melakukan perzinahan sedangkan mereka menjaga kehormatannya inilah yang disebabkan dilarang memaksa. Ayat ini diturunkan berkenaan dengan Abdullah ibnu Ubay, karena dia memaksakan hamba-hamba sahaya perempuannya untuk berpraktek pelacur dmi mencari keuntungan bagi dirinya.(As-Suyuthi, 2004, vol. III, hlm. 1469) Selain penafsiran diatas adapula beberapa pendapat mufassir lain mengenai kekerasan terhadap perempuan. Dibawah ini diterangkan beberapa pendapat lainnya.

\section{Pandangan Mufassir Mengenai Kekerasan terhadap perempuan Dalam Rumah Tangga}

Beberapa ahli tafsir mengemukakan pendapat yang berbeda mengenai tindak kekerasan terhadap istri. Apalagi ketika menjelaskan surah 
an-Nisa' ayat 34. Abu Hayyan al-Andalusi dalam tafsirnya Al-Bahr al-Muhit beliau mengatakan:

Dalam menghadapi istri yang nushuz, suami pertama kali menasehatinya dengan lembut, jika tidak efektif boleh dengan mengucapkan kata-kata kasar, jika (masih tidak efektif) membiarkannya sendiri tanpa digauli, kemudian jika masih tidak efektif bias memukulnya dengan ringan atau dengan cara lain yang membuatnya merasa tidak berharga, bias juga dengan mencambuk atau sejeneisnya sehingga membuat dirinya jera karena sakit. Dalam tafsir ini pemukulan yang diperbolehkan adalah pemukulan yang tidak membuatnya patah tulang dan berdarah. Dan ketika hal tersebut masih tidak efektif suami boleh memaksanya berhubungan seksual dengan mengikat tangan istri, karena itu adalah hak suami."(Hayyan al-Andalusi, 1993, vol. III, hlm. 252)

Dalam Tafsir al-Mawardi karya Abu al-Hasan 'Ali ibn Muhammad alMawardi mengemukakan beberapa pendapat mengenai Wahjuruhunna fi alma $d\{a j i$, salah satunya adalah pendapat Abu Ja'far al-Thabari yang menyatakan bahwa mengikat tangan istri dengan tambang dan memaksanya berhubungan seksual.(al-Mawardi, 1992, vol. I, hlm. 482)

Menurut Muhammad Abduh, Sayyid Quthub dan Wahbah al-Zuhaili kata "Qawwamun" lebih cenderung diartikan dengan "melindungi" dan "mengarahkan". Dalam kerangka tersebut laki-laki dituntut untuk memberikan perlindungan dan pengayoman terhadap perempuan. Akan tetapi, meskipun Allah menjadikan laki-laki sebagai pelindung dan pengayom hal tersebut tidak bermaksud menjadikan laki-laki sebagai penguasa atau untuk mendominasi perempuan. Sebagian penafsir seperti, Shaleh bin Fauzan, menyatakan bahwa ayat ini turun sebagai pengakuan bahwa pada zaman dahulu perempuan pernah menjadi bagian dikalangan masyarakat yang sangat rendah, sementara laki-laki dianggap paling unggul karena kekuasaan dan kemampuannya mencari nafkah.(Fauzan, 2001, hlm. 22)

Menurut Jalaludin as-Suyuthi penulis Tafsir Jalalain mengartikan kata "Qawwamun" sebagai pemimpin sehingga maknanya lak-laki adalah pemimpin atau penguasa bagi perempuan, baik itu dalam kehidupan rumah tangga ataupun kehidupan dalam bermasyarakat. Bahkan beberapa mufassir juga mengemukakan berbagai penjelasan tentang "bias laki-laki". Menurut an-Nawawi kata "Qawwamun" dimungkinkan beberapa alasan diantaranya karena laki-laki memiliki kesempurnaan akal (kamal al-aql), matang dalam perencanaan (husun at-ta'bir), memiliki penilaian yang tepat, serta mempunyai kelebihan keshalehan. Oleh sebab itu, laki-laki diberikan tugas istimewa sebagai Nabi, Imam, menjadi saksi dalam masalah, wajib jihad, 
shalat jum'at dan yang lainnya. Dengan kecenderungan tersebut menjadi faktor pendorong untuk mendukung pengutamaan laki-laki terhadap perempuan.

Dalam penafsiran Hamka dan Quraish Shihab dalam kecenderungan tersebut mengartika kalimat "Qawwamun" dengan "pukullah", tetapi indikasi tersebut untuk mendidik dan mengembalikan keharmonisan rumah tangga. Pemukulan yang diperintahkan oleh Quraish Shihab adalah pemukulan terhadap istri yang tidak baik, tidak taat kepada suami, dan tidak bisa dinasehati dan telah pisah ranjang. Pemukulan yang dibolehkan juga harus dengan cara yang tidak menyakitkan, tidak meninggalkan bekas dan tidak mencederai perempuan. Kecederungan tersebut bukanlah hal yang baru dalam kajian tafsir. Kitab-kitab rujukan seperti At-Thabari, al-Qurthubi dan Ibnu Katsir juga memberikan kecenderungan yang sama.(Kodir, 2011, hlm. 144-145)

Dalam Tafsir al-Munir ditegaskan bahwa memukul istri hanya dilakukan ketika benar-benar tidak bisa diatasi. Walaupun seperti itu, memukul bukanlah perilaku yang mulia dan sebaiknya tidak dipilih namun, jika dengan terpaksa melakukan pemukulan maka pemukulan tersebut dilakukan dengan tidak mencelakakan istri, tidak melukai, tidak meninggalkan bekas dan tidak berkali-kali. Memukul menurut an-Nawawi bisanya dilakukan dengan menggunakan sapu tangan yang lembut. Jadi, menurut mufassir abad ke-19 perintah memukul istri diartikan dengan memukul menggunakan sapu tangan yang lembut.(al-Nawawi, t.t., hlm. 5)

\section{Pencegahan Kekerasan Terhadap Perempuan Dalam Rumah Tangga}

Kekerasan terhadap perempuan adalah suatu bentuk kekerasan berbasis gender yang menyebabkan atau mengakibatkan rasa sakit dan penderitaan bagi perempuan, baik secara fisik maupun psikologis. Hal tersebut termasuk ancaman, paksaan, pembatas kebebasan, yang sering terjadi diarea publik maupun domestik. Adapun jenis-jenis kekerasan terhadap perempuan antara lain berupa kekerasan fisik, kekerasan psikis, kekerasan seksual, kekerasan ekonomi atau penelantaran. Dampak kekerasan terhadap perempuan dapat menimbulkan sakit secara fisik, mental, maupun produktivitas yang menurun.

Terjadinya kekerasan dalam rumah tangga merupaka salah satu akibat dari tidak adanya pengetahuan munakahat. Baik itu dari pihak suami ataupun istri. Sehingga tidak mewujudkan keluarga yang sakinnah ,mawaddah dan warrahmah. 
Bahkan dalam salah satu hadis Nabi SAW yang diriwayatkan oleh Tirmizi menyebutkan bahwa "Orang mukmin yang paling sempurna imannya ialah, yang paling baik akhlaknya dan paling ramah terhadap istrinya/keluarganya", atau dalam riwayat lain juga menyebutkan bahwa Rasulallah SAW telah bersabda:"...para suami yang memukul istrinya bukanlah termasuk orang-orang baik diantara kamu"(HR.Abu Daud, Nasa'I dan Ibnu Majah).

Islam melalui al-Qur'an dan Hadits menjelaskan bahwa Islam merupakan agama yang mengajarkan kedamaian terlebih dalam kehidupan berkeluarga, maka dari itu Allah memerintahkan hamba-hamba-Nya untuk membangun keluarga yang didasari dengan kasih sayang dan saling mencintai sebagaimana tercantum dalam surah Ar-Rum ayat 21.

Pencegahan tindak kekerasan dalam rumah tangga dapat mulai dilakukan pada masa awal sebelum perkawinan. Perkawinan dalam Islam pada hakikatnya bertujuan untuk mewujudkan kebahagiaan hidup suami istri dalam berkeuarga. Oleh sebab itu islam memberikan syarat kepada calon suami yang mana harus memiliki kemampuan sebelum melangsungkan perkawinan, seperti dalam hadis: "Wahai para pemuda barang siapa diantaramu telah memiliki kesanggupan, maka menikahlah karena menikah itu dapat menenangkan pandangan mata dan lebih menjaga kehormatan. Dan barang siapa belum mampu menikah maka hendaknya dia berpuasa karena itu dapat mengekang syahwat" (H.R Bukhari dan Muslim). Makna dari "kemampuan" bersifat umum yang dimaksudkan adalah kemampuan ekonomi, sehat jasmani, dan rohani (kematangan emosional), serta pengetahuan tentang hak dan kewajiban suami istri.(Jamaa, 2013, hlm. 77)

Suami harus memiliki pemikiran yang positif bahwasanya istri adalah titipan Tuhan yang harus yang harus di berikan rasa tanggung jawab, diperlakukan dengan baik sehingga budaya patriaki yang sudah mengakar dikalangan masyarakat tidak harus diterapkan karena hal tersebut bertentangan dengan konsep keluarga sakinah.

Faktor penghambat untuk menanggulangi tindak kekerasan dalam rumah tangga adalah sebagai berikut:

1. Keterbukaan dan saling percaya, dalam hubungan suami istri harus saling percaya dan bersikap terbuka jangan ada yang disembunyikan dari pasangan karena hal tersebut dapat memicu pertengkaran dan lambat laun akan terungkap.

2. Memahami kedudukan satu sama lain, hal tersebut perlu untuk menciptakan keharmonisan apalagi jika keduanya sama-sama bekerja. 
3. Menjauhi amarah, pertengkaran dalam rumah tangga merupakan hal yang sangat wajar akan menjadi tidak baik bila pertengkaran terjadi terus menerus dan akan diperparah jika salah satunya bersikukuh dengan pendapatnya sendiri. Dalam hubungan salah satu harus ada yang mengalah, bukan berarti dia kalah tapi disitulah hal kecil yang dapat mejadikan perdamaian. Seperti yang diterangkan dalam hadis Nabi bahwa berilah maaf pada istri, pasti ia akan memaafkanmu.(Sutrisminah, 2020, hlm. 7)

\section{PENUTUP}

Bentuk kekerasan digolongkan menjadi dua kategori yaitu kekerasan fisik dan non fisik. Kekerasan fisik seperti dalam surah an-Nisa' 19 dan 34 . Kekerasan non fisik seperti an-Nisa' ayat 20, 129 dan surah an-Nur ayat 33. Beberapa ayat diatas secara garis besar tidak menjelaskan tindak kekerasan tersebut secara langsung. Namun untuk golongan kekerasan fisik terkesan membolehkan kekerasan sedangkan untuk kekerasan non fisik lebih mengutamakan larangan. Penyebab terjadinya tindak kekerasan terhadap perempuan salah satunya dikarenakan faktor budaya yang mana seorang suami dianggap memiliki kekuasaan penuh terhadap perempuan ketika sudah berkeluarga seperti yang dijelaskan dalam awal surah an-Nisa' ayat 34 .

Ditinjau dari beberapa sumber penafsiran yang diambil penulis menyimpulkan bahwa beberapa mufassir memang ada yang membolehkan memukul perempuan dengan dalil suran an-Nisa' ayat 34. Namun, harus dipahami pula bagaimana proses membolehkan tersebut. Yaitu 1) menasehati, 2) menjauhi dengan pisah ranjang, 3) barulah memukul. Pukulan yang dimaksud pula adalah pukulan yang tidak menyakitkan yaitu pukulan yang tidak meninggalkan bekas.

Kekerasan dalam rumah tangga dapat diatasi pada masa awal sebelum perkawinan. Suami harus memiliki pemikiran yang positif bahwasanya istri adalah titipan Tuhan yang harus yang harus diberikan rasa tanggung jawab, diperlakukan dengan baik seperti dalam awal surah an-Nisa' ayat 34 bahwasanya laki-laki adalah pemimpin keluarga. Serta dalam kehidupan rumah tangga harus senantiasa menumbuhkan rasa cinta dan kasih sayang seperti dalam surah ar-Rum ayat 21. 


\section{AT-TIBYAN}

Journal Of Qur'an and Hadis Studies

Volume. 2 No. 1 (Juni 2019)

\section{REFERENSI}

al-Mawardi, A. al-H. 'Ali ibn M. (1992). Al-Nukat Wa Al-Uyun; Tafsir al-Mawardi. Dar Al-Kutub Al-Ilmiyah.

al-Nawawi, M. bin U. bin A. (t.t.). Syarh 'Uqud al-Lujjain fi Bayan Huquq az-Zawjayn. Syirkat Nur Asia.

al-Shiddieqy, T. M. H. (2000). Tafsir Al-Qur'anul Majid An-Nuur. Pustaka Rizki Putra. As-Suyuthi, J. (2004). Tafsir Jalalain. Sinar Baru Algensindo.

Fauzan, S. bin. (2001). Sentuhan Nilai Kefikihan Untuk Wanita Beriman. Mizan.

Hamka. (2003). Tafsir al-Azhar. Pustaka Nasional PTE LTD.

Hayyan al-Andalusi, A. (1993). Tafsir al-Bahr al-Muhith. Dar al-Kutub al-Ilmiyyah.

Jamaa, L. (2013). Kekerasan dalam Rumah Tangga Perspektif Fikih. AHKAM : Jurnal Ilmu Syariah, 13(1), Article 1. https://doi.org/10.15408/ajis.v13i1.952

Kodir, F. A. (2011). Islam dan Kekerasan Dalam Rumah Tangga (KDRT):

Pembahasan Dilema Ayat Pemukulan Istri (An-Nisa, 4: 34) Dalam Kajian

Tafsir Indonesia. Holistik, 12(1), Article 1.

https://doi.org/10.24235/holistik.v12i1.80

Lajnah Pentashih al-Qur'an. (2012). Al-Qur'an dan Terjemah. Syaamil Qur'an.

Muhajarah, K. (2017). KEKERASAN TERHADAP PEREMPUAN DALAM RUMAH

TANGGA: Perspektif Sosio-Budaya, Hukum, dan Agama. Sawwa: Jurnal Studi Gender, 11(2), 127-146. https://doi.org/10.21580/sa.v11i2.1452

Purba, L. (t.t.). Kekerasan Terhadap Perempuan: Kekerasan Dalam Rumah Tangga dan Perdagangan Orang. 10.

Setiawan, C. N., Bhima, S. K. L., \& Dhanardhono, T. (2018). FAKTOR-FAKTOR YANG MEMENGARUHI KEJADIAN KEKERASAN DALAM RUMAH TANGGA DAN PELAPORAN PADA PIHAK KEPOLISIAN. DIPONEGORO MEDICAL JOURNAL ( JURNAL KEDOKTERAN DIPONEGORO ), 7(1), 127-139.

Shihab, M. Q. (2018). Perempuan. Lentera Hati.

Sutrisminah, E. (2020). Dampak Kekerasan Pada Istri Dalam Rumah Tangga Terhadap Kesehatan Reproduksi. Majalah Ilmiah Sultan Agung, 50(127), 2334.

Umar, N. (1999). Kodrat Perempuan Dalam Islam. Lembaga Kajian Agama dan Gender. 